\title{
Firms Strategies and Their Three Elements
}

The name of competitive strategy itself contains the ideology of how to compete. Unlike competitive strategy, the names of corporate strategies do not contain the overall guidelines required by the strategy itself. Therefore, to make them have the attribute of strategy, the decision makers need to put forward the guiding ideology which fits well with the actual situation of the firm and the environmental characteristics, so as to guide the tactics.

\subsection{Introduction}

In the Chapter of Tactics and Three Tactical Elements of Strategy, we have mentioned certain strategies such as cost leadership, hybrid, mergers \& acquisitions, integration, etc. What about the three elements of those strategies? In the following, we will address that concern.

Generally, there are three levels of company strategies (see Fig. 6.1): Corporate Strategy, Competitive Strategy, or SBU Strategy (Strategic Business Unit-SBU), Functional Strategy.

Corporate Strategy takes a portfolio approach to strategic decisions by looking at all of the company's businesses to determine how to create the most value. In order to develop corporate strategies, companies must study how the various businesses they own fit together, and how parent companies are structured to optimize human capital, processes, and governance.

Competitive Strategy refers to a long-term plan made by a company to gain competitive advantage over its competitors in the industry. The goal is to establish a defensive position in an industry and generate a higher financial performance. 
Fig. 6.1 Multi-level Strategies

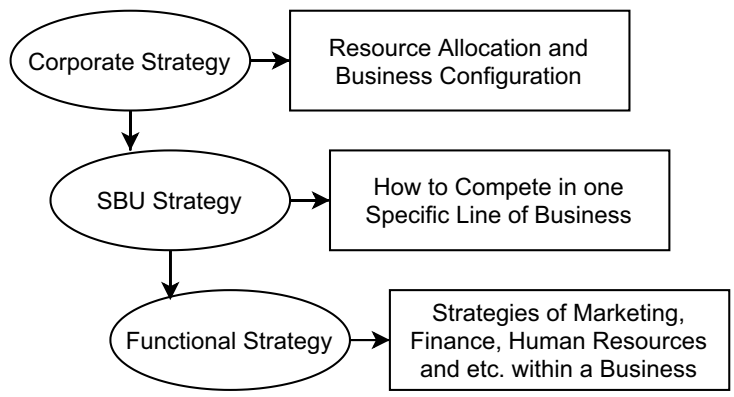

Functional Strategy refers to the strategy or organizational plan adopted by each functional department, namely market, production, finance and human resources, to achieve organizational goals in line with the overall business or corporate strategy. A company's functional strategy is tailored for a specific industry or strategic business unit (SBU) to support other strategies.

Here we discuss solely on the Corporate Strategy and Competitive Strategy.

\subsection{Competitive Strategies and Their Three Elements}

My literature review found that the Competitive Strategy (or SBU Strategy) has been well studied and concluded into systematic academic fruition due to contributions of Porter (1997), Bowman and Faulkner (1997) and Mintzberg (1988). Let us look at its three elements of competitive strategies.

SBU is a strategic concept, which refers to a division managed independently by a large company, whose planning is done separately from other businesses of the company. It has its own products and services, or a specific line of business, its own competitors and potential competitors in the market in the industry. Generally, the SBU of a company is held accountable for its own performance in sales, profits and other indicators. The objectives of the division are different from the parent company and crucial to the long-term performance of the enterprise.

Mintzberg believes that the duty of senior management in a SBU is to know how to compete, which Porter argues that it is to create competitive edges. Competitive Strategy is about how to create and maintain company's competitive advantage, on which is where SBU Strategy focuses. Several competitive strategies proposed by Porter and Bowman are commonly accepted in business practices and academic communications despite Galbraith and Schendel's (1983) contribution to the study of corporate strategy types and categorization.

Porter (1997) argues that there are three types of strategies, which are capable of creating competitive advantages: Cost Leadership, Differentiation and Focused strategy (Integration of Cost Leadership \& Differentiation).

Bowman (1997) proposed Strategic Clock Model or SCM, which offers even more options than Porter's Competitive Strategy. In his view, Competitive Strategy may fit into the following categories: Cost Leadership, Differentiation, Hybrid, Focused Differentiation, and Segment Specific etc. (see Fig. 6.2). 
Fig. 6.2 Strategy Clock Model (from Bowman and Faulkner 1997)

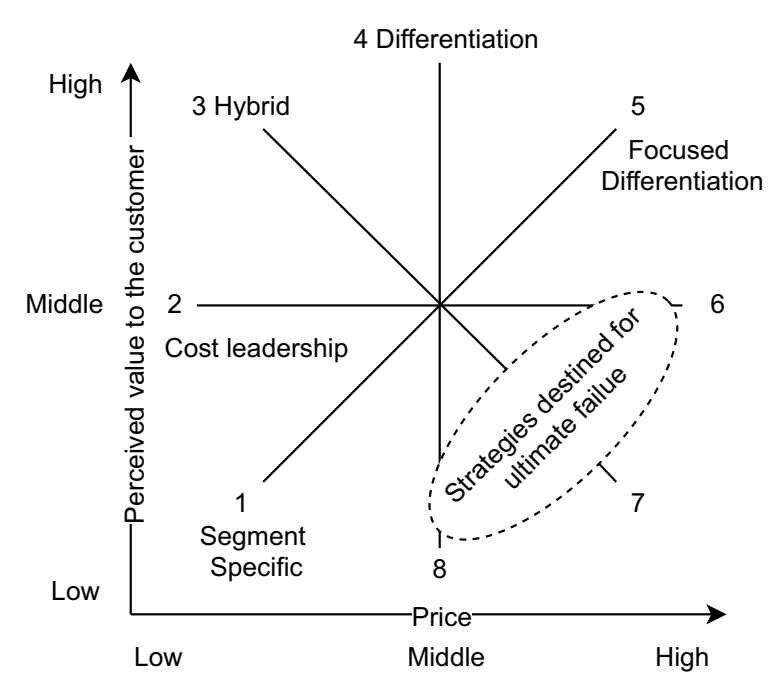

Taking the price of product (service) as the abscissa axis, and added value as the ordinate axis, the strategic clock model (SCM) draws out different competitive strategies available for companies.

Competitive strategy with low price and low value (Position 1): By focusing on consumers that are quite sensitive to prices, a company may cater to the market by lowering the value of the product (or service), like the less expensive geriatric cellular phones designed for old people with fewer functions.

Low Cost Competitive Strategy (Position 2): This strategy is also known as cost-leadership strategy. The strategy was represented by Porter's Cost Leadership theory. The choice of cost-leadership dictates the enterprise to discover and tap advantageous resources and sell standardized and plain products to pursue success associated with scale of production and economies of scale. For seizing the competitive advantages, Cost Leadership is featured with 2 basic characteristics: First, market positioning which is on the mass; Second, in the case of a fiercely competitive market, companies who adopt cost leadership strategy will attract more consumers with pricing mechanism (lower price) without profit losses.

Hybrid (Position 3): A hybrid position, or value for money strategy, indicates consumers enjoying value-added products or services but with low price. The strategy provides the ideology that consumers do not necessarily have to pay a higher price for better quality. It is exceedingly appealing to consumers. However, we know that providing customers with good products or services requires the company to do good research on customers' demands with capability of turning the research results into good products, which will generally lead to higher costs. To balance costs, prices and developing new products, as an optimized state pictured by the strategy is without doubt challenging many companies. When the company is able to find ways to reduce costs without sacrificing value, or able to reduce costs associated with economies of scale by boosting sales when consumers in the market is huge in numbers, Hybrid Strategy is a good choice. 
Differentiation Strategy (Position 4): The option requires the enterprises to offer customers the high level of perceived added value. Through differentiation companies distinguishes their products with that of the competitors', thereby gaining additional revenues. The core of Differentiation is that the needs of consumers in the market are diversified and cannot be met with single standard products. Enterprises offer customers perceived added value at a price higher than competitors by providing better products or services in order to secure more market shares and increased revenue.

Focused Differentiation Strategy (Position 5): This strategy aims to position products or services in high quality (higher than other products in market), where price-insensitive customers would buy for perceived added value. Highest quality of the products or services in the industry often implies their highest selling prices.

High Price and Low Value Strategy (Position 6, 7, 8): Products or services with low value sold at high prices are, when there are other competitors in the market, doomed to be unsalable. Customers will not buy the products and the enterprises will not adopt the strategies in the first place. A company will position their products in Position 6,7,8 under none but two following circumstances:

- Monopoly Pricing: consumers have to buy monopolist's products without alternatives.

- Firms in Position 4 are forced to remove here due to fierce competition in industry. One case is that prior to the birth of iPhone, the gigantic Nokia, Motorola, Ericsson positioned their products in Position 4 (differentiation). IPhone was a subversive innovation with only a bit higher selling price. However, consumers perceived much more value in iPhone than any others did. Therefore, non-smart phones from Nokia, Motorola, and Ericsson was shifted from position 4 to High Price, Low Value (See Figure below). The same thing happened on Taobao and eBay Eachnet where Taobao had launched better, cheaper platform and eBay Eachnet was relocated.

Thus, we can see that a company is not static in competitive position, when the company neglects the development of competitors in the market; they are not far from relocation. (Fig. 6.3).

Porter also proposed Focus Strategy, where companies focus efforts on one or two niche market segments to better meet the consumer needs of that target market. The gist of it is to avoid competition with main competitors in the market and to target market segments where the competition is weak. The exemplary case is Wahaha, a nutritional food company founded in the 1980s in China, inspired by the Chinese traditional medical theory of food therapy, developed and sold a kind of nutrition oral liquid targeted for children who do not like eating and it was a huge success. In a niche market, a firm typically looks to gain a competitive advantage by adopting cost leadership or differentiation.

We have introduced several major competitive strategies. From above introduction of the basic contents of the competition strategies, we can tell that names of these strategies imply the basic guiding ideologies on how to compete. Cost 
Fig. 6.3 Shift of Competition Position

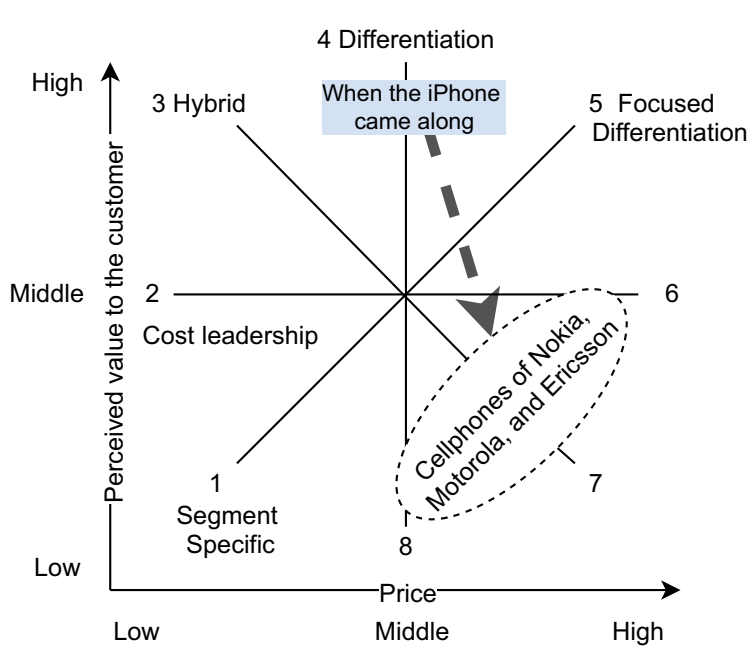

leadership is as simple as "my cost is lower than my competitors". Low cost is not the ends rather the means to appeal to customers with perceived added value and lower price. Understanding that is going to prescribe competitive behaviors in markets.

In addition, differentiation is to promote products or services that are different from competitors' in order to appeal to customers. Corresponding tactics can be derived from here.

Each strategy above is reflective of competitive thinking behind it.

According to the above introduction, competitive strategies imply rich thoughts on how to compete in market, thus the thoughts can be used to guide the company business in the market competition. Let us go back to the three elements of strategy concept. As introduced before, the general guiding ideology of the three elements lies at the bottom right of the triangle of strategy concept. Guiding ideology reflected in competitive strategies are thus located in the bottom right of the triangle of strategy (see Fig. 6.4).

Fig. 6.4 Three Elements of Competitive Strategy

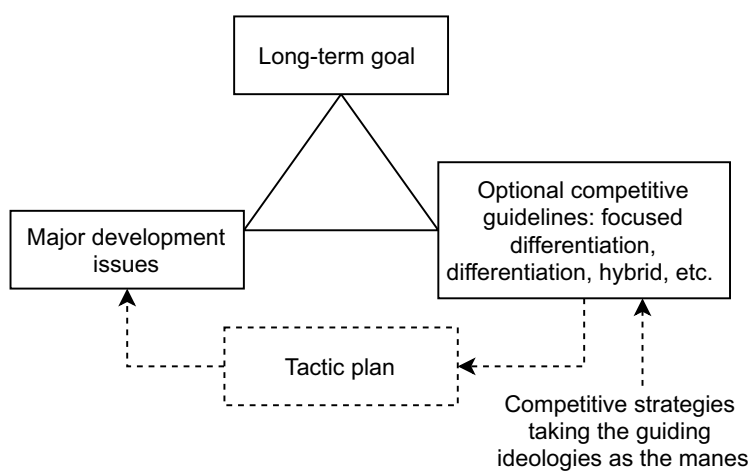


The guiding ideology of strategy serves for tactics. Under the thoughts of differentiation strategy, a company adopts competitive tactics according to its market position. Suppose a company selects Hybrid as its competitive strategy, what kind of detailed tactics shall be accepted for attracting consumers are factored by markets, competitors, company resources and capabilities. Taobao's hybrid strategy is well executed by diverse tactics that are reflective of the strategic thinking (See Chapter of "Tactics and the three elements of strategy"). In Chap. 5, we mentioned that tactical plans should be included in competitive strategy. Though their names imply ideologies for competition, strategy without tactics in practice cannot gain competitive advantages. Companies ought to come up with own competitive tactics or plans to contend for customers in markets.

Let us look at the three elements and tactics of the two most commonly used strategies, which are differentiation and cost Leadership.

There have been some studies on differentiation. Mintzberg (1988) put forward certain themes (or tactical directions): price, image, design, quality, and support. The Figure below shows how the three elements of differentiation strategy and tactics interacts (Fig. 6.5).

Cost Leadership strategy is well studied as well. Porter (1985) in his book Competitive Strategy, mentioned many ways to reach cost leadership, which are specific tactics to lower costs. The Figure below shows how the three elements of cost leadership strategy and its tactics interacts (Fig. 6.6).

We can know from above that most of the things about the competition strategy have been paid attention and are well studied. The reasons to say this are as follows:

First, from the perspective of the three elements of strategy, all competitive strategies have demonstrated clear general guiding ideologies that produce competitive tactics or plans for instruction.

Second, competitive strategies displayed in Strategic Clock are a complete set, applicable in enterprises with different business scale, type, and characteristics.

Third, the studies on differentiation themes for differentiation strategy and on cost-saving plans for cost-leadership strategy are relatively mature.

Fig. 6.5 Differentiation Strategy and Tactic Themes

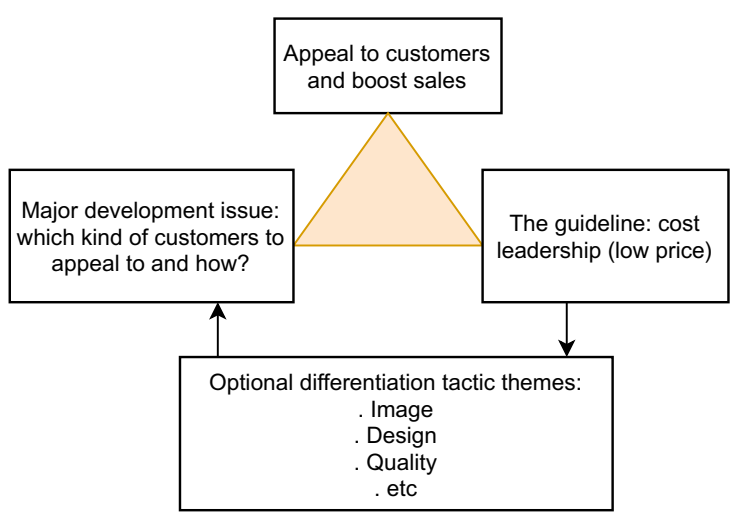


Fig. 6.6 Three Elements and Tactics of Cost Leadership Strategy

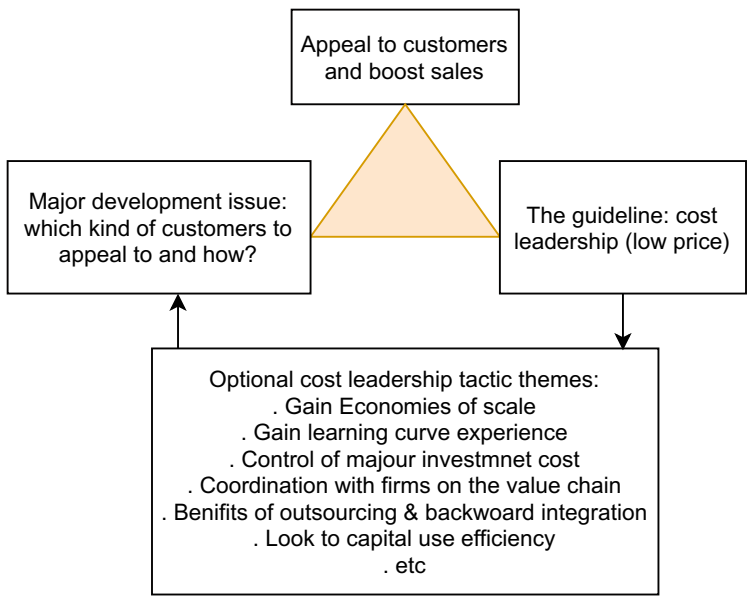

One of the most important criteria testing on theoretical maturity is its explanatory and practical application nature. In that sense, competitive strategies have emerged as a system with its theoretical functions.

Tributes shall be given to three professors: Michael Porter, who firstly proposed the concept of competitive strategies; Henry Mintzberg, whose studies on differentiation provided theoretical basis for differentiation tactics; Cliff Bowman, who proposed strategic clock model that improves competitive strategies. All their theories shed light on competitive strategies and make a huge difference on business strategic choices.

\subsection{Corporate Strategy}

Now we look at Corporate Strategy.

The term corporate, group or group company can often be seen in media and some company's websites.

A corporate group is a collection of subsidiary companies that function as a single economic entity through a common source of control. There are two types. One that is involved in a number of business fields by holding subsidiaries respectively (wholly owned subsidiaries and holding subsidiaries). The parent company here is sometimes referred to as corporate group. The other kind of corporate group can be owned by a holding company, which may do not have actual operations. The top-level headquarters are responsible for corporate finance and capital operation, assessment of financial performance of subsidiary companies and oversight of senior management in subsidiary companies. Decision-making power is largely delegated to subordinate companies with its own leaders make the call and corporate company sees to it that subsidiary companies meet financial goals each year. 
Our discussion here must be limited to the first type of organizations.

Corporate group manages its subsidiaries in many forms that are as generalized as centralization of power, decentralization of power.

A centralized organization is one which decision-making power on major organization development issues is largely limited in the headquarters or a higher level of authority, which take regulatory management over subordinate companies in $\mathrm{R} \& \mathrm{D}$, quality control, human resources, and even marketing. After the decision is taken, it is communicated to the lower level managers who are expected to follow the orders.

A decentralized group company is, on the contrary, one in which part of decision-making power is delegated to subordinate companies who can make their own strategic plans of aimed goals and corresponding resources investment decisions (on funding and human resources). Subordinate companies' plans are generally subject to review and approval by the headquarters.

What strategic decisions are there to be made by senior management in corporate companies?

The goal of the corporate strategy is to optimize resource and business allocation and to develop businesses in different markets, and to navigate subsidiary companies to pursue greatest corporate effects (scale effect, scope effect, speed effect, etc.). Therefore, senior management in the headquarter have to answer to the major questions of targeted market, business scope, capital flow, shut-down or selling businesses.

Corporate strategies in our discussion are as below.

\section{(1) Strategic decision to guide business of SBU}

Corporate group, either centralized or decentralized, needs a guideline on how subordinate companies compete in the markets. Though the corporate group does not directly compete in the market, some more centralized companies have to make strategic decisions on how their subordinate companies compete globally. For example, low-end products from other companies were affecting SKF. Should the company follow competitors' footstep of low-price position? The headquarter needed to make the decision. The headquarter decided to compete by differentiating their products from competitors', which has had a profound influence in guidance on its SBUs or subordinate companies.

Sometimes the market is so diverse that the corporate group needs to decide on whether to adopt multiple competitive strategies at the same time. Such as the Volkswagen being a high-end product for Chinese consumers in 1990s due to their low income at that period. Volkswagen China needed to meet the Chinese market and enter the low-end market (by adopting cost leadership strategy). The Volkswagen headquarter then had to make that decision accordingly.

Under loose management, the corporate group usually does not exert influence on competitive strategy of subordinate companies and authorizes senior managements of the subordinate companies to make decisions on these issues. 


\section{(2) Decision on business contraction (remote) and expansion}

Changes in regional economic growth, cultural practices and industry policies will bring about changes in consumer in the number of buyers, consumers' purchasing power and their desire to buy in different markets. In addition, the growing market may become depressed. The originally underdeveloped markets, thanks to rapid economic growth, will become tempting. Market changes are threats and opportunities to companies depending on the strategic decisions and judgment made by senior management of the corporate group.

In 2007, impacted by the subprime mortgage crisis, the US economy fell with only $1.7 \%$ GDP growth rate with $62 \%$ year-on-year drop in 2008, and a worsening $2.1 \%$ decrease in 2009. Ford Motor Company suffered a huge deficit and the senior management must make decisions to deal with it. In order to reduce deficit and debt and restore profitability, the company decided to sell unprofitable brands, Jaguar and Land Rover to India's Tata Motors Group, and then sold Volvo to China's Geely Automobile on Dec. 2010.

Let us look at decisions on business expansion. In the early 1980s, China, after nearly 40 years of planned economy, was seeing a rapid economic growth brought by the implemented Reform and Opening Door Policy. GDP annual growth rate soared to $9.1 \%$ in 1982 and up to $15.2 \%$ in 1984 . However, annual per capita disposable income was then still low: $565 ¥$ in 1983 and $651 ¥$ in 1984 . A family’s income was impossible to buy cars. Foreign automobile manufacturers were concerned about the Chinese market, and their senior management were weighing up the decisions on whether, when and how to enter the Chinese market. Volkswagen, as we all know, was the first to take action and enter China by setting up a joint venture, Shanghai Volkswagen Automobile Co., Ltd. with the Shanghai Automotive Group back in 1985. The US General Motors followed the step much later in 1997 and founded Shanghai General Motors Co., Ltd. These strategic moves are the implementation of the two company's strategies concerning China market.

Sometimes even in the same country, due to economic and cultural differences among different regions, regional markets present different characteristics. For example, China's eastern provinces are more developed than western ones, the provincial capitals, other common cities. Different developmental characteristics determine different corporate competitive and developmental strategies in different regions.

In addition, strategic decisions should be made by the headquarter of the corporate group when changes in competition conditions impose grave influence on business operations.

\section{(3) Strategic decision to enter another industry}

Sometimes when there is an industry market that is seeing rapid development and high profitability, many companies, though whose main businesses are irrelevant, are tempted and decide to take the share of the market. That decision-making is the strategy of unrelated diversification. Generally, as the business has no experience in 
the new market and does not know if the product is going to be successful, its entry or not will be determined by the strategic decision-making of senior management.

In the late 1990s, a new policy was implemented in real estate industry and housing system of residents in China, a change from planned allocation to market economy. The real estate market was booming, as it never has, due to the huge demand, which was an opportunity for companies who had nothing to do with real estate. Some entered the market and turned out to be a huge success, while some also did and ended up in bankruptcy.

When the industry of the company's main business is decreasing, the decision-makers need to find new directions for the future development of the company's business. Therefore, decisions are usually needed to enter other industries which known as unrelated diversification in academic society.

Wahaha, a Chinese company, suffered from the development bottleneck of declining sales revenue, owing to the intense competition in beverage industry in China in around 2010. The company decided to reduce dependence on beverage business and looked for new profit growth point. Its diversification attempts were entry into the retail industry and liquor business. In the early 2012, Wahaha united some of its distributors, established a joint venture of Wahaha Commercial Co., Ltd, and created WAOW PLAZA, a retail mall with the first phase of investment of 1.7 billion RMB. In 2013, thanks to government introduction, Wahaha reached a partnership with Jinjiang Liquor, a hundred-year-old brewery in the renowned place for spiced liquor production, Maotai County. Wahaha invested 10.5 billion RMB and held $80 \%$ of the share in the company. Targeted at grassroots, it sold its products at the price of 100-400 RMB.

Apart from unrelated diversification, corporate decisions need to be made regarding the entry into industry-related business fields (not main business), such as parts and material suppliers business or distributors' business fields and branding.

Mobile phone chip is a kind of IC classification, is a kind of circuit module which integrates a variety of electronic components on the silicon board to achieve a specific function. It is the most important part of electronic equipment, which undertakes the function of calculation and storage. Qualcomm, Apple Inc., Intel Corporation, Samsung and Mediatek Inc. of Taiwan are the main producers of chips. Due to the high concentration of the chip industry, mobile phone manufacturers do not have the initiative. China has a large mobile phone market. Huawei is a main mobile phone manufacturer in China. Despite high technical requirements, in 2000, Huawei made a strategic decision to entering into chip area, in order to free from the dependence on mobile chip suppliers. This is an example of related diversification as well as an example of backward integration.

\section{(4) Strategic decision on corporate transition}

Sometimes senior management may sense the imperative of development redirection signaled often by performance decline or ceiling effect of development. IBM, a long-term leader in the computer industry, had the most remarkable achievement in 
large/small machines and portable machines (ThinkPad). The standard of personal computer (PC), which was founded, is still continuously used and developed. Its PC business suffered continued deficits of US\$ 397 million in 2001, US\$ 171 million in 2002, US\$ 258 million in 2003, and US\$ 139 million in 2004, adding up to over US\$ 1 billion, as shown in the financial report it submitted to the US Securities and Exchange Commission. IBM made a strategic decision to sell the PC business and focus on minicomputers, mainframe and server products for transition.

Powerlong Real Estate is a commercial real estate enterprise (stock code HK1238), founded in 2003 by Powerlong Group in China. Based on the idea of urbanization development strategy of China, its business mainly focuses on the Tier 3 and Tier 4 cities of China. In 2013, a decade after its establishment, it decided to renew its corporate strategy and proposed the transformation strategy of 'Shanghai as the center, focusing on the Yangtze River Delta and Fujian Province and Shandong Province'. XU Huafang, the president of the company, believed that real estate projects are comparatively riskier in Tier 3 and Tier 4 cities with low consumption capacity and the lack of talents despite the low costs than those Tier One and Tier Two cities with high consumption capacity, bountiful talents and stable revenue despite the high costs. In this knowledge, the change of corporate strategy from the pursuit of quantity to the pursuit of quality is understood.

\subsection{Corporate Strategies and Their Three Elements}

Above are brief examples of corporate strategic decisions. Let us have a look at the relationship between strategies at corporate level and their three elements.

I find, in comparison to strategies at business unit level, the academic community has not yet contributed adequate results in research of corporate strategy perhaps because of its complex, multifactorial nature. Hence, here, I am afraid I cannot illustrate the three factors in one figure as systematically as in the introduction to competitive strategies at present. As difficult as it might be, I will attempt in my best effort to simplify the question and elaborate on each strategy respectively.

In view of the nomenclatural system of strategies (multiple names can refer to one strategy), our discussion will be limited within the most commonplace strategies.

\section{(1) Integration strategy}

Integration strategies in some books are classified into the subgroups of horizontal integration and vertical integration, or forward integration and backward integration.

Horizontal integration refers to mergers \& acquisitions of additional business activities that are at the same level of the value chain in similar or different industries. Vertical integration is a strategy where a company expands its business 
operations into different steps on the same production path, either in the front-end or in the back-end of the industrial value chain. Integration strategy refers, in a narrow sense, to backward integration and forward integration.

Forward Integration.

Forward integration is a business strategy that involves a form of vertical integration whereby business activities are expanded to include control over the direct distribution or supply of a company's products. Say Company A is professional in OEM (Original Equipment Manufacturer), and forward integration for the company is to create its own brand to consolidate its production, distributors, retailers, etc., and, to expand its business activities to sales. The maturity of Internet technology makes forward integration easier and a more popular approach to business strategy.

Forward integration is often adopted for companies in situations where sellers cannot meet enterprises' needs (costs, etc.), sales are considerably profitable, enterprises have funds and human resources to sell products or services, and enterprises desire to know better about market information and consumers' needs.

Nanfeng Chemicals in Shanxi Province in China was an OEM for starters. In 1992, it established the brand KEON whose products include washing powder, soap, washing liquid, toothpaste, etc. With its sales now among the best in the country, its forward integration worked.

So, what are the three elements of forward integration?

First, it is a goal-oriented strategy. We can see that from its basic idea-to enter sales. Second, we can find no guiding principle in its definition (see Fig. 6.7). Unlike competitive strategy, integration strategy in its explanation cannot shed a practical light on integration tactics. This means a company is still perplexed with all the options ahead - to start its own brand, or to build its own sales network, or to buy shares of an existing brands (to become controlling shareholder) in the market, or to acquire an enterprise in the market. All these are left to corporate decision-makers to ponder on.

Therefore, a complete version of forward integration shall include decision-maker's guiding principle. Company executives need to come up with basic guidelines about whether to build their own sales channels or buy existing

Fig. 6.7 Forward Integration Strategy (simplified)

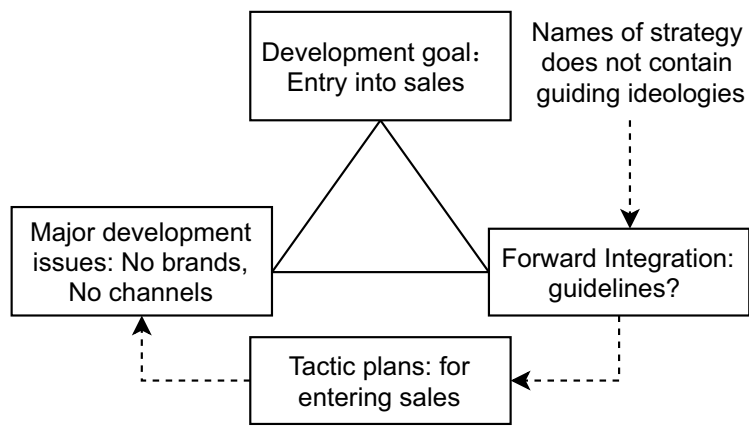




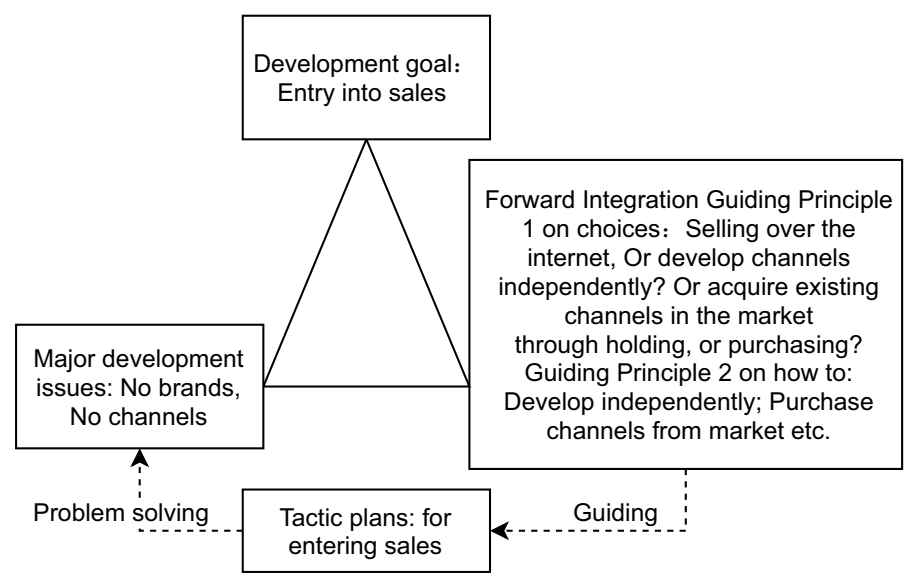

Fig. 6.8 Forward Integration Strategy (complete)

ones from the market. If an acquisition is confirmed, the company's top management also needs to come up with basic guidelines on how to do it. With the two basic guidelines, a detailed tactical plan can be developed. Figure 6.8 shows the three elements of forward integration with major issue of having no sales channels.

\section{(2) Backward integration}

Backward integration is a form of vertical integration that involves taking place of, or buying shares of, or establishing strategic alliances with, suppliers up the supply chain to control self-made raw materials or spare and accessory parts what was to be outsourced before. Companies usually adopt the backward integration strategy under the following circumstances where suppliers are too costly or providing products of unstable quality or considerably profitable.

Iron ore is indispensable in steel smelting industry. China's demand for iron ore has been rising since 1990s driven by China's rapid economic development. Benchmark contract for iron ore (iron 62\%) in December 14, 2012 was US\$ 132.75 a ton, which was $150 \%$ of the annual low of US\$ 88.75 a ton 3 month ago, a violent fluctuation any company reluctant to see. For some companies in the industry, backward integration would be clearly an option.

Geely Automobile, in the early stage of its development, mostly relied on import of its engines. The engines were essential yet so expensive for manufacturing cars at competitive prices. As a result, since 2002, Geely began to independently develop engines and with its first engine MR479QA debut in the same year in Ningbo in China. Soon afterwards, Geely has launched engines with displacement of 1.3L, $1.5 \mathrm{~L}, 1.6 \mathrm{~L}$, and $1.8 \mathrm{~L}$ with independent intellectual property rights.

Why did Geely choose to develop engines independently rather than purchasing engine manufacturers to meet the demand for engines? LI Shufu, the president of Geely Automobile had his considerations that a large sum of money to be spent in 


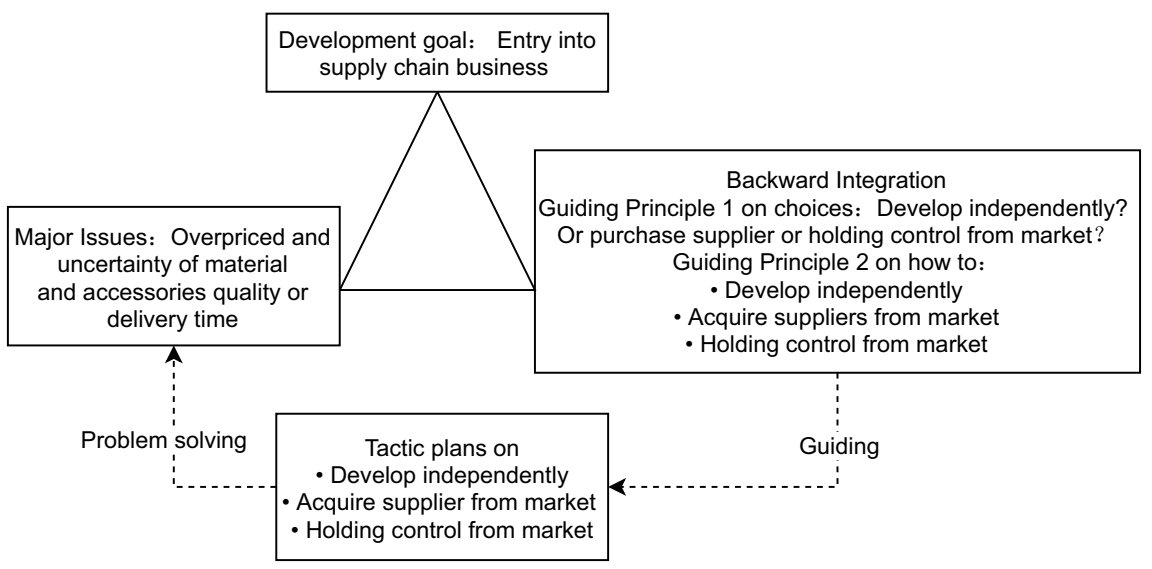

Fig. 6.9 Backward Integration Strategy (complete)

making acquisition is not worthy for a company that had not yet achieved profitability and developed financial strength.

Above are examples on backward integration. Let us look at the three elements of this strategy.

Backward integration has a clear goal - to enter the supply chain of raw material and spare parts to cope with uncertainties of price, quality and delivery time from suppliers. Now the goal and major issue of the three elements are clear enough, which leaves the general guiding ideology unanswered. How to enter the business? By starting own business (Greenfield approach) or acquiring or shareholding existing businesses in the market? If purchasing, what kind of targeted organization? These questions need to answer in detail that demands ideological principles to guild the tactic plans. Hence, the name of the backward integration strategy itself does not contain the guiding ideology of the strategy. Therefore, a complete backward integration strategy needs to put forward the guiding principle to direct the tactics (see figure below). (Fig. 6.9).

\section{(3) Acquisition strategy}

An acquisition is a corporate action in which a company buys another (David, 1998), or if not all, of another firm's ownership stakes to assume control of it. China's Securities Law stipulates that the acquisition refer to the takeover bid for the shares of a listed company when holding over $30 \%$ of the shares of it. The controlling power of the business allows the acquirer to make decisions about the newly acquired assets without the approval of the company's shareholders. 
Such acquisitions are related diversifications when companies acquire homogeneous businesses; and backward integration is when acquiring suppliers on the value chain; and forward integration when acquiring sales businesses (suppose the company's main business is in production) on the value chain. It is unrelated diversification when acquiring businesses are not related to its main business. Though there are various names, they can refer to one strategy some times.

Acquisitions are made out of the following goals: (1) Rapid expansion of market share of company's main business; (2) Obtaining of advanced technology; (3) Entry into new fields (new industry); (4) Obtaining of low-cost resources in the downstream of the value chain; (5) Acquisition of brands and marketing channels in the upstream of the value chain, etc.

The Table 6.1 summarizes the relationship of names of strategies and their goals.

The table has a few of implications that acquisition is probably the solution to realize new developmental objectives (goal-oriented acquisition) or to overcome developmental difficulties (problem-oriented acquisition). The three elements of acquisition strategy are shown in Fig. 6.10.

Similar to backward and forward integration strategies, we can see that there are no guiding ideologies or principles in the name of acquisition strategy. So, a whole set of acquisition decision-making further requires senior management to devise general guiding ideologies which provides instructions on planning acquisition tactics based on practical conditions like acquisition goals, corporate characteristics and the market conditions.

Take acquisition of technology from market as an example. The company probably prioritizes on targeted enterprises with small size, technologically advanced on the merit of low costs and simpler post-merger integration.

Table 6.1 Acquisition and other strategic terms

\begin{tabular}{|c|c|c|c|}
\hline Name & Definition & Other Strategic Terms & Aims (Goals) \\
\hline \multirow[t]{4}{*}{ Acquisition } & $\begin{array}{l}\text { To acquire } \\
\text { homogeneous } \\
\text { businesses }\end{array}$ & $\begin{array}{l}\text { Horizontal } \\
\text { Acquisition }\end{array}$ & $\begin{array}{l}\text { To eliminate competition; } \\
\text { acquire economy of scale; } \\
\text { obtaining of resources and } \\
\text { capabilities }\end{array}$ \\
\hline & $\begin{array}{l}\text { To acquire } \\
\text { suppliers on the } \\
\text { value chain }\end{array}$ & $\begin{array}{l}\text { Backward } \\
\text { Acquisition, Related } \\
\text { Diversification, } \\
\text { Vertical Integration, }\end{array}$ & Obtaining of low-cost material \\
\hline & $\begin{array}{l}\text { To acquire } \\
\text { front-end } \\
\text { businesses on the } \\
\text { value chain }\end{array}$ & $\begin{array}{l}\text { Forward Acquisition, } \\
\text { Related } \\
\text { Diversification } \\
\text { Vertical Integration, }\end{array}$ & Obtaining of valued business \\
\hline & $\begin{array}{l}\text { To acquire } \\
\text { businesses } \\
\text { unrelated to its } \\
\text { main business }\end{array}$ & $\begin{array}{l}\text { Unrelated } \\
\text { Diversification }\end{array}$ & Entry into a promising industry \\
\hline
\end{tabular}


Fig. 6.10 Acquisition strategy (simplified)

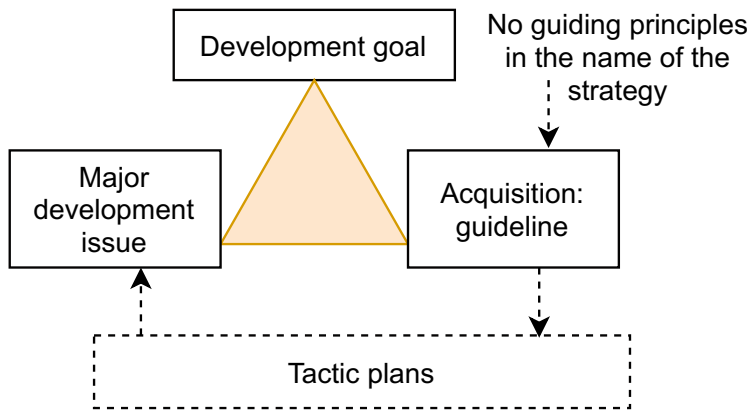

Sometimes, different companies may develop different acquisition principles or ideologies even at the same acquisition purposes. For example, with the same purpose to obtain technology from the market, the acquisition principles of a small company will be different from that of a large company. Specific principles could be varied depending on the targets.

Figure 6.11 is here below to show the elements of technology-oriented acquisition strategy.

As acquisition strategy has different purposes, we can have a more comprehensive figure (below) to show the elements of acquisition strategies with different objectives (Fig. 6.12).

Acquisition refers to organization buying or holding shares of company in the market. The element at the lower right of the triangle is the general guiding principles or ideologies of acquisition. It provides guidance for the acquisition tactic plans. The guiding principles in the triangle are important, indispensable component of the Acquisition Strategy. In the case of Greatwall Computer in China, as previously introduced in Chapter Five Tactic and Elements of Strategy, we can see how the guiding principle shed a light on its buying tactic plans.

Hence, the acquisition strategy in its name does not contain any guidelines for the development of tactic plans. Acquisition activities would have no train of thoughts without clear guidelines. The Ministry of Chinese Commerce (2016) reported that until the end of 2016, "more than $50 \%$ of Chinese enterprises are not

Fig. 6.11 Three Elements of Acquisition for Obtaining of Technologies

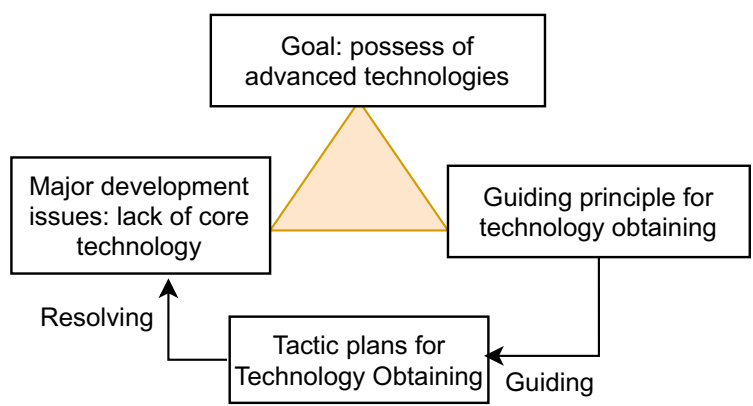




\begin{tabular}{|c|c|}
\hline \multicolumn{2}{|c|}{$\begin{array}{c}\text { Development Goal } \\
\text {. Acquire Technology } \\
\text { Or Reduce competition, expand market shares, achieve economies of scale } \\
\text {. Or Obtain sales channels } \\
\text {. Or Obtain suppliers' business on the industry value chain } \\
\text {. Or Enter into other industry and acquire resources }\end{array}$} \\
\hline \multirow[t]{2}{*}{$\begin{array}{c}\text { Major } \\
\text { issues in corporate } \\
\text { development }\end{array}$} & $\begin{array}{l}\text { Acquisition general guiding ideology on how to } \\
\text {. Acquire technology } \\
\text {. Expand market share and acquire economies of scale } \\
\text {. Obtain sales channels } \\
\text {. Acquire suppliers' business on the industry value chain } \\
\text {. Enter into other industry and acquire resources }\end{array}$ \\
\hline & $\downarrow$ \\
\hline \multicolumn{2}{|c|}{$\begin{array}{l}\text { Acquisition tactics: } \\
\text { Acquire Technology } \\
\text { Eliminate competition, expand market shares, and achieve economies of scale } \\
\text { Obtain sales channels } \\
\text { Obtain suppliers' business on the industry value chain } \\
\text { Enter into other industry and acquire resources }\end{array}$} \\
\hline
\end{tabular}

Fig. 6.12 Three Elements of Acquisition Strategy (completed)

successful in overseas mergers and acquisitions. ....... Only 13\% are in a profitable State".

One of the reasons that many acquisition strategies failed is very likely due to their decision-makers did not fully understand the gravity of the guiding principles of the Three Elements and turned their action into a blind hunt. It is fallacious to believe acquisition strategy alone enables a company to fulfil its goal of acquisition.

\section{(4) Diversification strategy}

Diversification strategy is an operation action in businesses of two or more different products or services. It is relative to another term specialized operation and can be classified into related diversification and unrelated diversification.

Related diversification is a process that adds new products and services related to the original business, or adds activities supplementary or complementary and supportive to the main business, or when there are competitively valuable relationships among the activities comprising their respective value chains. The motivations for related diversification are various. High price of suppliers' products and high profitability of suppliers' industry are the main motivations for companies to enter the suppliers' industry.

Unrelated diversification is a process that adds new products and services, which are not related to the original business, or entering into an industry that is not related with the company's business. The motivations for Unrelated Diversification are mainly: (1) The recession of main business urges the company to open up new 
market; (2) Targeted industry is rapidly growing and lucrative that appeals to the company; (3) The company has surplus funds and human resources that need to be profitable when main businesses have no potential for growth. Of course, all the Diversification Strategies have bearing with senior decision-makers, who may decide to enter one industry they are optimistic about.

The related diversification of adding businesses associated with the suppliers in the industry is also known as Backward Integration. Other than by undertaking independent R\&D in the case of Geely Automobile, many companies achieve Backward Integration and Diversification by acquisition business from market.

You may probably have noticed the phenomenon that a diversification strategy can have more than one name. What then exactly is the strategy when it takes several names? What are the three elements of those strategies?

We can find that indeed diversification (entry into supply, sales, unrelated businesses, etc.) is a goal companies wish to achieve. A single element of "goal" cannot make a strategy. The element at the bottom right of the triangle is unknown. From this point, Diversification Strategy in its name reference does not reveal its guiding principles and pathway to accomplishment, which accounts for many failed diversification attempts.

The goal of diversification concerns with an organization's future development direction, is delicate, and has to be the result of scrupulous observation and analysis of the company and the industry. Then what does the question mark in Fig. 6.13 represents?

Let us look at Related Diversification. Generally, the senior management knows the major problems in corporate development, as LI Shufu knew engines are vital in automobile industry and his company could not manufacture them.

We have known a strategy has to make decisions on three questions, to two of which Related Diversification has answered. The two questions answered concern with the goal and development. However, decisions must be made on the bottom right of the strategy triangle — general guiding ideology about choice and about how to obtain a business. There are three approaches that a company may obtain a business: to purchase, to buy shares of, to start its own. Decision-makers need to supplement the decision and the tactic plans after the decision is made, or in the

Fig. 6.13 Diversification Strategy (incomplete)

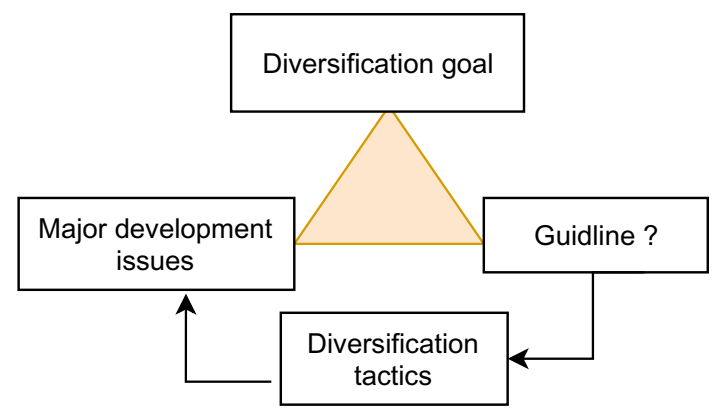




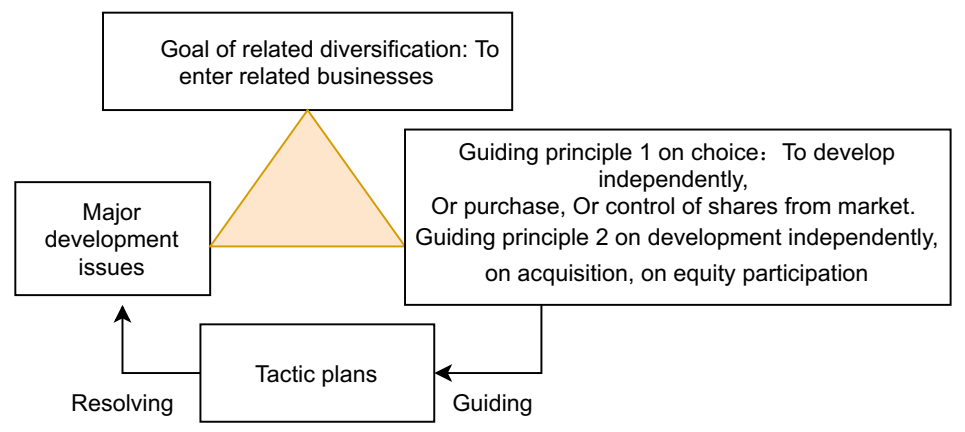

Fig. 6.14 Three Elements of Related Diversification Strategy

sense of strategy and tactic by providing guiding principles (see principle 1 and principle 2 in below figure). The principles will steer the design and selection of specific tactic plans. Figure 6.14 shows the elements of Related Diversification.

Now we move on to Unrelated Diversification.

If, out of some reason, the senior management of a company has made the decision to enter unrelated business. The goal is defined, here again; the name of this strategy, for its own does not entail any guiding ideologies or principles.

Even when executives have made the decision to enter into a business that is not related with company's main business (Unrelated Diversification), it still requires decisions on following questions:

- What industry to enter?

- How to enter the industry (by purchasing? by holding shares? by starting new businesses)?

- What kind of company to purchase or hold shares of ?

Those questions need to be addressed in order to provide general guidelines for tactic plans of unrelated diversification strategy, hence there are three guiding principles on the bottom right of the triangle. (Fig. 6.15).

Unrelated diversification is rather complicated as it requires making additional decision on what industry to enter, which makes even more complicated comparing with strategic decision of related diversification. Any mistakes in the decisions for questions located at the bottom right of the strategy triangle will account for the error of this strategy. This may explains why this strategy accounts for more failures comparing with others.

The decision on what industry to enter (Guiding Principle 1) is crucial. The choice of errors will lead to the failure of the whole strategy. Professor Chris Zook (2007) proposed in his paper Finding Your Next Core Business published on Harvard Business Review in 2007, that if the core of your business is nearing depletion, to venture dramatically away from it is more likely to a failure of an 


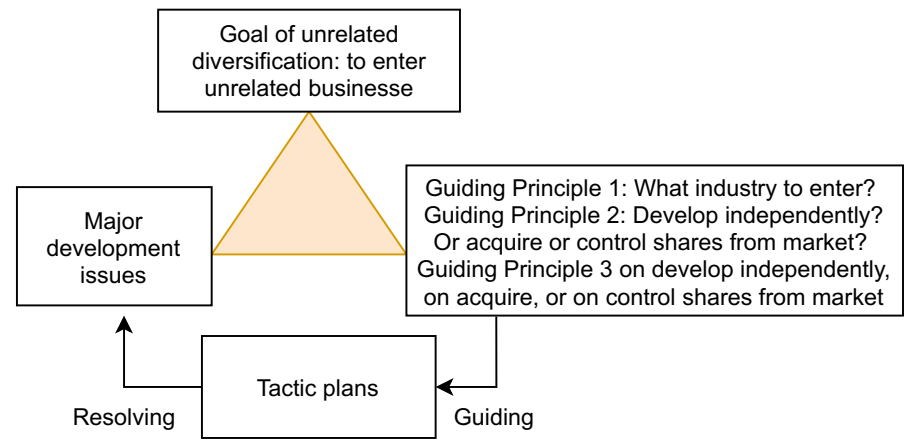

Fig. 6.15 Three Elements of Unrelated Diversification strategy

organization' new strategic. He thinks three hidden assets can be the centerpiece of the developmental strategy.

- Undervalued business platform (new business can be developed based on this platform)

- Untapped insights into customers (take the company's existing customers as the base of business development)

- Unexploited company capabilities.

In the viewpoint of resource-based view, new growth could rely on resources or capabilities that a company has. Unrelated diversification is not to venture into new business without recognizing existing resources. Professor Zook proposed the concept of 3 hidden assets that provides his version of "the guiding principle 1" of "what business to enter".

\section{(5) Market development strategy}

Market development is a growth strategy that identifies and develops new market segments for current products given that perhaps the current market tends to be saturated and the new market has growing potential. Market development is a goal-oriented strategy as a company has set a goal. From the strategy's three elements point of view, goal is on the top of the triangle and key problems is on the bottom left.

However, the name of this strategy itself does not have or imply a guiding ideology, or there is no guiding principle for decisions on where and how in the reference of market development strategy. Hence, the bottom right element of this strategy, the guiding principle of market development is blanked (see figure below). In the sense of strategy, it is incomplete (Fig. 6.16). To make this strategy be 
Fig. 6.16 Market

Development Strategy

(uncompleted)

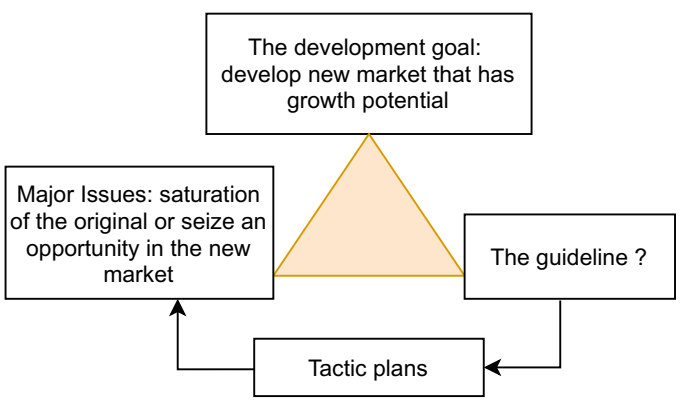

functional, the senior management needs to make decisions on where and how to develop markets.

In market development strategy, where to go is the paramount concern. Sometimes the answer is out of question like in the 1990s almost all the foreign companies' interest in China's fast-growing economy and market potential. Sometimes it can be tricky like when China's economy starts to slow down and if a company's main business is banking. Where should it go for new market? Senior management needs to have their guiding principles or ideologies on the issue.

Besides, to think about the question of where to go, it is also necessary for decision makers to give a thought on the pattern of ownership - to start a firm with sole proprietorship or a joint venture with a local firm. If it is a joint venture, with which or what kind of company? They are all big choices to make. Strategically speaking, all decisions concerning these questions need to be made out of the general guiding principles. Now a complete version of market development strategy, with which decision makers need to put forward 3 guiding principles, is displayed here in Fig. 6.17.

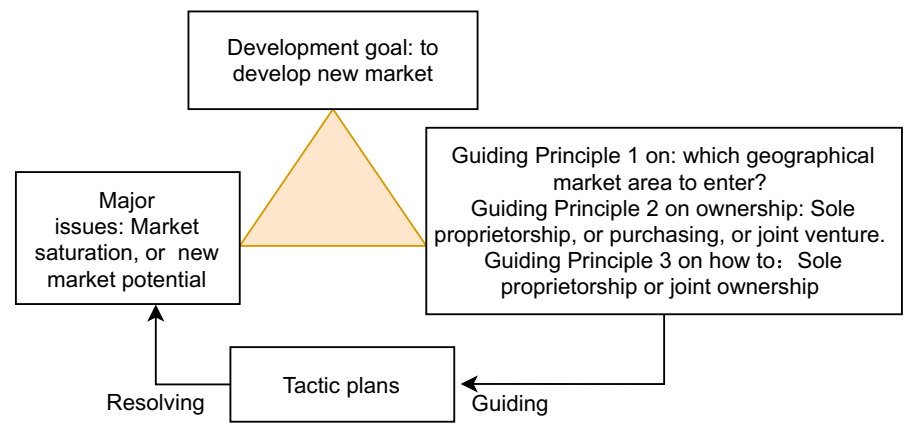

Fig. 6.17 Three Elements of Market Development Strategy 


\subsection{Strategies and Their Three Elements in Tradition}

There were many famous military strategic philosophies in Chinese history, in Sunzi's The Art of War, Sun Bin's Art of War, Mao Zedong's military ideas, thoughts of all the most sophisticated wisdom.

What is the relationship of strategy in the common sense and the three elements of strategy?

I would like to quote from Stratagem, the Art of War. "In the practical art of war, the best of all is to take the enemy's country whole and intact; to shatter and destroy it is not so good. So, too, it is better to recapture an army entire than destroy it, to capture a regiment, a detachment or a company entire than to destroy them. Hence to fight and conquer in all your battles is not supreme excellence; supreme excellence consists in breaking the enemy's resistance without fighting."

Many wars in ancient times, even in victory, would devour a country's wealth and human resources, plunging people into the abyss of misery and destitution, costing lives of many excellent soldiers and generals. Victory without fighting is without question a blessing of people and country. The ideology put forward by Sun Tzu's art of war is an important thought of war. From the perspective of three elements of strategy, the goal is of course, victory of war, and the strategic issue that has to be dealt with should be "War brings losses and suffering to the people and the army." There arises the idea of "victory without fighting", a profound philosophy. (Fig. 6.18).

In the early days of the Communist revolution, Chairman Mao and other revolutionists, who have struggled for years with enemies and gained experience against stronger enemies, put forward the policy of "Sixteen Words" that defeated the enemy. The essence of the policy was to deploy military forces flexibly, to foster strengths and circumvent weaknesses, to preserve strength and to eliminate enemy forces in guerrilla warfare. It plays a vital role in changing the balance of military strength and is the guiding principle in the strategic triangle.

We can see in military practices, some strategic guidelines show up spontaneously in the names of "guidelines", "general policy", aiming to cope with big issue and serve the purpose of victory.

Therefore, in fact, those military "strategies", as often mentioned in traditions, refer to the general guiding principle or ideology at the bottom right of the triangle of three elements of strategy.

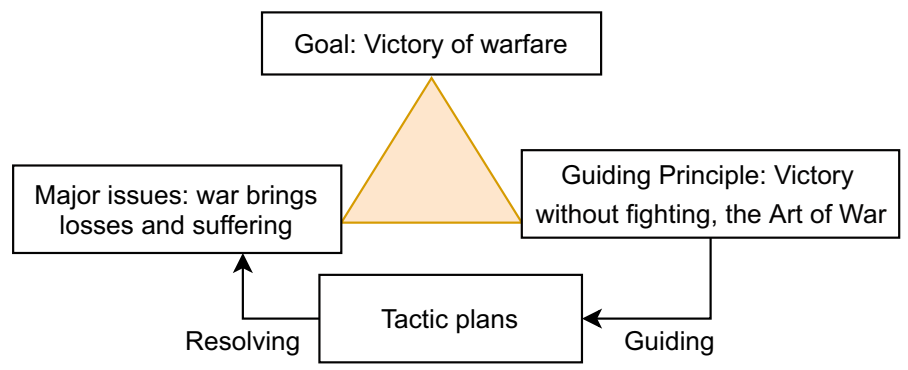

Fig. 6.18 Sunzi’s Military Philosophy of "victory without fighting" 
Moreover, are traditional strategies in their content, the guiding principle of the three elements of strategy? Porter's four competitive strategies for SBU (cost leadership, diversification, etc.), Bowman's strategic clock model are theories on how to compete and appeal to customers. For example, Cost leadership aims to provide products and services for mainly price-sensitive customers with low price; Diversification strategy argues about distinguishing own products and services from competitors' in order to win the favor of targeted customers. So similar to the situation of military strategy, they shall also lie at the bottom right of the triangle of the three elements of strategy.

In contrast, traditional corporate strategies such as acquisition, diversification, forward integration and backward integration etc. in the sense of their names, do not possess much philosophical thinking and thus cannot to be applied as the guiding principle in specific conditions. In the content reflected in their names, corporate strategies are basically expected goals. For example, "forward integration" refers to enter into brand, channels and sales; "backward integration" shows to entry to supplier's business; and "diversification" represents getting into related or unrelated business. So, many traditional strategies at corporate level, in the sense of names, they are the "goal" element in the three element of strategy.

\subsection{Concluding Remarks}

We have introduced three elements of many strategies. Competitive strategies for SBU have guiding principles in their content while certain corporate strategies do not. To make corporate strategies bear property of STRATEGY, general guiding principles or ideologies must be generated or developed based on practical conditions to provide guidance for formulating tactic plans in the next step.

Strategies, rather than tactics, are more of philosophies, a product of intellectual mind. Blaise Pascal, an extraordinary mathematician, physicist and philosopher in the seventeenth century, once noted Thought makes the whole dignity of man. A good guiding principle will elevate the wisdom of a company strategy.

It is worth noting that a strategy consisting three elements is a complete one, but not necessarily a good one. Right decisions need to be made on all three elements. Though we have assigned a seat for philosophy, guiding principles and ideologies for the bottom right element of strategy triangle, their existence is so ubiquitous in the framework that a strategic goal has to be out of philosophical thoughts. Strategies are distinguished from tactics with their philosophical nature and shall not live up to their names if devoid of strategical thoughts.

It is no easy task for senior decision-makers to set up company's long-term goal and to identify major development issue. It even require enough wisdom and profound understandings to find strategic solutions (general guiding ideologies and tactic plans) to important development issue. Strategies, as decisions made by senior management is mirroring their makers' mentalities. 


\section{References}

Bowman, C., \& Faulkner, D. (1997). Competitive and corporate strategy, 296. London: Irwin.

Galbraith, C., \& Schendel, D. (1983). An emperical analysis of strategy types. Strategic Management Journal, 4, 153-173.

Mintzberg, H. (1988). Generic strategies: Towards a comprehensive framework, advances in strategic management. Greenwich: JAI press.

Porter, M. E. (1985). Competitive advantage: Creating and sustaining superior performance. New York: Free Press.

Porter, M. E. (1997). Competiteive Strategy (in Chinese), Translated by Chen, Xiaoyue. Beijing: Huaxia Publishing House.

Zook, C. (2007). Find your next core business. Harvard Business Review, 85(9), 66-75.

Open Access This chapter is licensed under the terms of the Creative Commons Attribution 4.0 International License (http://creativecommons.org/licenses/by/4.0/), which permits use, sharing, adaptation, distribution and reproduction in any medium or format, as long as you give appropriate credit to the original author(s) and the source, provide a link to the Creative Commons license and indicate if changes were made.

The images or other third party material in this chapter are included in the chapter's Creative Commons license, unless indicated otherwise in a credit line to the material. If material is not included in the chapter's Creative Commons license and your intended use is not permitted by statutory regulation or exceeds the permitted use, you will need to obtain permission directly from the copyright holder.

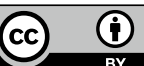

